These facts have emerged from accounts of the centenary sent to us by Profs. Alexander Schneiderman, Alexander Popov, Nikolai Williams, B. Shiskin, and others.

The Moscow centenary meetings included one held at the Timiriazer Agricultural Academy (the oldest agricultural school in the Union) at which Alexander Paramonov read a paper on "Timiriazev as the Founder of Russian Darwinists", and others spoke on botanical problems. At a meeting in the Moscow Scientists' Club, there were present members of the Academy of Sciences of the U.S.S.R., the Lenin Academy of Agricultural Sciences, University of Moscow, and others. The Vice-President of the Academy of Sciences, Leon Orbeli, said in an introductory speech that whole generations had been and were being trained on the basis of Timiriazev's classic work "The Life of Plants". The eighty-yearold Victor Krasilnikov followed with a portrait of Timiriazev as a "Knight of Science". Krasilnikov did not simply relate, but re-lived the past, and mentioned that one of Timiriazev's aims had been the creation of hundreds of experimental fields in every province. Timiriazev's activity did not find much practical support in pre-revolutionary times, but Trofim Lysenko pointed out that much of the present Russian drive for increased agricultural production could be ascribed to the spirit of Timiriazev. At this meeting, congratulatory telegrams were read from the Royal Society, the Royal Agricultural Society of England, and Rothamsted Experimental Station.

The Timiriazev Agricultural Academy is indeed playing a great part in Soviet agriculture. President Kalinin, chairman of the Presidium of the Supreme Soviet, has expressed the desire that the influence of the Agricultural Academy should be extended to collective farms throughout the country and should embrace all cultivation. Important steps in such extension work have already been made in many districts in European and Asiatic Russia.

In 1903 Timiriazev gave the Croonian Lecture, and eight years later was elected foreign məmber, of the Royal Society. He was also doctor honoris causa of the Universities of Cambridge, Glasgow and Geneva, and was a member of the Edinburgh and Manchester Botanical Societies. These foreign memberships were and are a source of much prite to the Russian people, and Timiriazev's statue in the centre of Moscow shows him robed in a Cambridge gown.

\section{CARNEGIE INSTITUTION OF WASHINGTON}

Y

EAR BOOK No. 4] of the Carnegie Institution of Washington covers the year July 1, 1941June 30,1942 , and in addition to the reports of the executive committee, the auditors and the president, includes the reports of the departmental activities and co-operative studies. In regard to war activities, the president states that the policy of the Institution, in carrying on war research for the Government, has been to contribute the use of its facilities, the services of its regular scientific staff and its regular overhead costs of providing administrative services and the like: The Institution is reimbursed for all additional out-of-pocket expenises directly attributable to the research for Government. In addition, it has loaned the services of some of its scientific personnel while retaining them on the pay-roll. In regard to finance, the favourable financial situation of the Institution which existed for three decades no longer persists, and for the first time in the history of the Institution the budget involves even a small predicted deficit. There is still some room for retrenchment, and a deficit appears for one reason because the annual grant from the Carnegie Corporation of New York is carried in a separate account since it is of a terminating nature. The downward trend of income from 1,695,900 dollars in 1936 to an estimated income of $1,175,000$ dollars for 1943 if continued will, however, soon involve retrenchment of the regular operation of the departments.

Among the results of many investigations undertaken at the Mount Wilson Observatory, special reference is made to the increase in our knowledge of solar prominences, solar rotation and the general magnetic field of the sun through the application of powerful interference methods; to the analysis of the gaseous clouds of interstellar space and to the probable solution of the long-standing problem of the direction of rotation of the extragalactic spiral nebule. Activities of the Geophysical Laboratory and the Department of Terrestrial Magnetism have been directed so exclusively to war research that there is little to report. Priorities have, however, now been obtained for the materials necessary to complete the cyclotron at the Department of Terrestrial Magnetism, which is expected to be available for use during the coming winter. In the field of terrestrial sciences a number of reports of work on cosmic ray research at the Universities of Chicago and New York, the California Institute of Technology and elsewhere are included.

In the Division of Plant Biology further work has been carried out on the variables of the photosynthetic processes, structural elements in the higher plants and differences and relations in climatic races of flowering plants. Several projects have been completed on the influence of a desert environment on plant-growth, and it has been discovered that diatoms and related plants contain chlorophylls which are different from those of land plants. The Department of Embryology has continued its work along previous lines, and knowledge of the development of the human embryo has been pushed back about one week to the eighth day of gestation. Effective co-operation has been continued between the Department of Genetics and the Long Island Biological Association at Cold Spring Harbor. Detailed studies at the Department of Tenetics of genetic effects caused by X-rays, ultra-violet rays and neutrons show consistent differences between the action of these radiations. Compared with gene mutations, fewer chromosomal breaks are caused by ultra-violet radiation than by $\mathrm{X}$-rays, whereas the neutrons show a higher rate of chromosomal breaks than X-rays. Nearly six years study of the role of hormones in the regulation of the maternal instinct in rats has been completed by Dr. Riddle and his associates, who have found that the pituitary gland hormones play an important part in the production of stimuli that result in unlearned maternal behaviour. The Department has also co-operated with the Bureau of Plant Industry and the U.S. Department of Agriculture on problems arising from the war emergency, and is experimenting with the rubber-producing Russian dandelion and with fibre-producing hemp. 
The small staff of the Nutrition Laboratory has been engaged in important war research in cooperation with groups at the Harvard Medical School. Projects under the Division of Historical Research have been of interest in supplementing the Government's programme of inter-American cultural relations. The knowledge possessed by the staff members of this Division with regard to geographical and economic conditions in Central America is also proving of assistance in connexion with the Government's war programme.

\section{ACID NEUTRALIZATION IN INSULATING PAPERS}

$\mathrm{T}$ the manufacture of paper-insulated condensers, 1 impregnating materials are used to eliminate air pockets and to increase the dielectric capacity of the paper. With long use, particularly at high temperatures and under high voltages, traces of hydrochloric acid are liberated from chlorinated impregnants. The acid, and the salts formed by its reaction with the metal electrodes, ultimately decompose the paper and break down the condenser. . This destruction is delayed by calcium, magnesium and other metals combined chemically with the paper which neutralize the hydrochloric acid.

An article by D. A. McLean (Bell Lab. Rec., 21, No. 6 ; Feb. 1943) gives some of the results of an investigation carried out on the properties of Kraft and linen papers. Exchange reactions in cellulose materials do not take place in the principal constituent but in other organic materials with which cellulose is always associated, including lignin, pectic substances and pentosans. Differences in content of these minor components explain why papers differ so greatly in exchange capacity. Kraft paper, which is much superior to linen for condenser insulation, has several times the exchange capacity of linen tissue. In apparatus with which accelerated lifetests of condenser papers are carried out, condenscrs are heated in an oil bath and a continuous record made of the leakage current until the paper under test breaks down.

When aluminium electrodes are used in condensers made with paper impregnated with chlorinated compounds, decomposition of the dielectric proceeds from central nuclei about which the paper becomes partially carbonized. If the sample is dismantled after accelerated tests at high temperature and with D.\%. voltage, these areas can be seen as brown spots. Under ordinary artificial light a photograph shows dark spots on a light background, but with ultraviolet light the spots fluoresce brightly.

Papers of high exchange capacity are capable of suppressing the formation of decomposed areas, and in two samples taken from a condenser after approximately equal periods of test at the same voltage, linen paper is shown to become thickly populated. with decomposed areas which have grown from minute centres seen scattered through the sample, whereas Kraft paper shows only slight evidence of decomposition. More severe conditions of test are required to produce serious deterioration in the Kraft paper.

Superiority. of Kraft paper as a dielectric is illus: trated by comparing the energy losses at elevated temperatures in condensers made with this material and with linen. The lower power factor in Kraft paper is due to the binding of ionic material by its base exchange properties, which decreases the A.c. losses. Values given in the article were determined at low potential gradients, under which conditions ionization is most readily detected by A.C. measurements. Condenser papers of high exehange capacity reduce leakage current, and typical results obtained with linen paper under accelerated test conditions show a rapid increase of leakage and dielectric failure after 40 hours. In contrast, Kraft paper has a much more stable leakage eurrent and a life of 350 hours, as its high base exchange capacity suppresses decomposition. These studies of exchange reactions in condenser papers impregnated with chlorinated compounds have led to the development of stabilizers which extend the life of condensers, under stated severe test conditions, to several thousand hours.

\section{APPOINTMENTS VACANT}

Applications are invited for the following appointments on or before the dates mentioned:

Head OF THE Electrical EngINEering DEPARTMENT-The Registrar, Technical College, Sunderland (August 6)

LECTURER (MAN OR 'WOMAN) IN CHEMISTRY in the Croydon Polytechnic-The Education Officer, Education Office, Katharine Street, Croydon (August 6).

SPEECH THERAPIST (full-time)-The Secretary for Education, Education Offices, York (August 6).

Graduate assistant Master to teach EnginenRing Drawing in the Middlesbrough Technical School for Boys-The Director of Education, Education Offices, Middlesbrough (August 7).

TEACHER OF MINING SuBJECTs in the Denbighshire Technical College, Wrexham-The Director of Education, Education Offices, Ruthin (August 7).

ASSISTANT MASTHR (preferably a Graduate with works experience) to teach TECHNICAL DRAWING AND MATHEMatics in the Sunderland Junior Technical School-The Director of Education, Education Offices, Carlton House, Mowbray Road, Sunderland (August 9).

Assistant to teach Mathematics and other Junior Engineering Subjects-The Principal, County Technical College and School of Art, Newark, Notts. (August 9).

Lectorer in Mathematics in the Constantine Technical College, Middlesbrough-The Director of Education, Education Offices, Middlesbrough (August 14).

HeAD OF THE DEPARTMENT OF ChILD DEVELOPMENT In succession to Dr. Susan Isaacs-The Secretary, University of London Institute of Education, at. University College, Nottingham (August 14).

LeCTURER (TEMPORARY) IN PHYsICS-The Acting Secretary of University Court, The University, Glasgow (August 15).

assistant Lecturer and Demonstrator IN The Physiology DEPARTMENT-The Secretary, The University, Birmingham (August 18).

LeCTURER (TEMPORARY) IN CheMistrY-The Registrar, University College, Southampton (August 25).

Professor of Physiology, a Senior Lecturer in ANatomy, and A SENIOR LECTURER IN PHYSIOLOGY, in the University of Otago, Dunedin-The High Commissioner for New Zealand, 415 Strand; London, W.C.2 (August 31).

CHEMIST AND ASSAYER on the establishment of the South African Mint, Pretoria-The Secretary, Office of the High Commissioner for the Union of South Africa, South Africa House, Trafalgar Square, London, W.C.2 (August 31)

Heads OF THE Departments of Phystology, Medicine, and SURGERY-The Bursar, Royal Veterinary College and Hospital, at The University, Reading (October 1).

ChaIr of Naval ARchitecture-The Acting Secretary of University Court, The University, Glasgow (October 4).

ENGINEERING WORKSHOP INSTRUCTOR for service in the Bury Junior Technical School and Bury Municipal Technical College (Even ing Classes)-The Director of Education, Education Offices, Bury.

\section{REPORTS and other PUBLICATIONS (not included in the monthly Books Supploment) Great Britain and Ireland}

Young Workers and their Education: Providing the Kight Type of Education and Problems of Release from Work: A Report of a Conference held at the College of Technology, Manchester, April 15th; 1943, under the auspices of the British Association for Commercial and Industrial Education. Pp. 40. (London: British Association
for Commercial and Industrial Education.) 1s. Geological Survey of Great Britain : England and Wales. Wartime Pamphlet No. 33: Glauconite Sand of Bracklesham Beds, London Basin. By Dr. Kenneth P. Oakley. Pp. 28. (London: Geological Survey and Museum.) 18. $6 d$. 